\title{
Characteristics of Choral Writing in György Ligeti’s Late Works*
}

\author{
A.S. Ryzhinskii \\ Gnesins' Russian Academy of Music, \\ 30-36, Povarskaya str., Moscow, 121069, Russian Federation
}

For citation: Ryzhinskii, Aleksandr. "Characteristics of Choral Writing in György Ligeti’s Late Works”. Vestnik of Saint Petersburg University. Arts 8, no. 4 (2018): 578-92. https://doi.org/10.21638/ spbu15.2018.403

Article is devoted to the last vocal works a cappella created György Ligeti in 1980 - the $1990^{\text {th }}$ years: "Drei Phantasien nach Fridrich Hölderlin", "Magyar Etüdök" and "Nonsense Madrigals". The author traces relationship between the previous and last choral opuses by the master, between Ligeti's choral works and choral creativity of his predecessors and contemporaries. So the author reveals features of ligeti's late choral style: at the levels of relationship between word and music, the texture and timbre organization. The author pays special attention to studying of Ligeti's neomadrigalism. This phenomenon proves in the organization of musical texture, in interaction of musical and literary texts and also in the general organization of compositions. The opposition of love and death (immemorial categories of human life) is the cornerstone of the dramaturgic organization of a cycle and typical for Ligeti's vocal works "polyphony of meanings" is shown in the constant present genre and style game with the recipient. The composition intended for "The King's singers" embodies diverse style hints, corresponding to the wide performing range of this ensemble and own musical interests of the composer. In this last vocal work by Ligeti also his love to literary world of Lewis Carroll with the atmosphere of absurdity, so conformable to the music world of the author of "Le Grand Macabre" was reflected.

Keywords: György Ligeti, Arnold Schönberg, Luigi Nono, Lewis Carroll, Fridrich Hölderlin, choral music, texture, vocal timbres, neomadrigalism.

Almost 10 years lie between Ligeti's late choral and vocal ensemble opuses and vocal compositions of the 1960s-1970s. Apart from choral episodes in opera Le Grand Macabre, Ligeti never turned to composing for a chorus or a vocal ensemble after 1973. Referencing certain composer's statements ${ }^{1}$, one could suppose that Ligeti's temporary lack of attention to choral genres was not intentional, but rather conditioned by orders for orchestral compositions ${ }^{2}$ and working on the opera during that period.

Despite obvious links between Ligeti's late vocal compositions and the 1960s works (focus both on vocal ensemble /Nonsense Madrigals/ and on proper choral compositions /Drei Phantasien nach Friedrich Hölderlin, Magyar Etüdök/, similar texture pattern and timbre devices), the 1980s works also showcase new trends in the composer's choral writ-

* The reported study was funded by RFBR according to the research project №16-04-50011.

${ }^{1}$ So, speaking of his reasons to temporarily put aside vocal music after 1965, the composer noted: 'It was not intentional. In fact, I was planning to work on the opera after Aventures in 1965' [1, p. 52].

2 Among them are, for example, San Francisco Polyphony commissioned by San Francisco Symphony in 1974 .

(c) Санкт-Петербургский государственный университет, 2018 
ing. If we do not consider rather vague verbal text in Requiem choral parts, it is in Drei Phantasien nach Friedrich Hölderlin and in Magyar Etüdök that the composer for the first time based a choral composition on poetic works with the text clearly distinctive in a number of cases. Besides, it is during that period that Ligeti's choral music moves towards lengthier melodic horizontals (the composer wittingly called this development stage of his micropolyphonic style 'less micro' [2, p.36]) and recognizable chord structures (both poly - and monointerval ones) while having more uniform vocal timbre compared to the 1960s opuses.

Already the first composition opening composer's late choral work, Drei Phantasien nach Friedrich Hölderlin (Three Fantasies after Friedrich Hölderlin; 1982-1983), shows greater attention to homogeneous timbre sonority. The composer mainly uses classical vocalisation, in certain cases resorting to falsetto. The main types of setting in Ligeti's choral opuses - polyphonic and harmonic texture - coexist in this composition not only alternating, but also overlapping. The overall texture of the cycle directly depends on Friedrich Hölderlin's poetical text, resorting to which, despite being the only case in Ligeti's choral legacy, still seems very symptomatic for Western European music of that period. Starting from 1964 - the first production of Hyperion by Bruno Maderna - Hölderlin's poetry becomes a constant object of regard for post-war avant-garde composers. Among the most famous examples of turning to his work are Die Jahreszeiten by Heinz Holliger, quartet Fragmente - Stille, an Diotima and Prometeo by Luigi Nono ${ }^{3}$.

When answering a question on his reasons to turn to Hölderlin's poetry in this composition, Ligeti said: 'Why I picked Hölderlin: he is a favorite poet, and not only to me. But for the "composing" I actually chose the poetic fragments because of their wonderful imagery and their emotional aura' [4, p. 151]. Constantin Floros established Ligeti's principle for selecting poems in his monograph: 'The three poems fit as well together as if they constituted a cycle. Central to them is the contrast between illusion and truth, between appearance and reality, between a happy past and a painful present' [4, p. 151]. The contrast that C. Floros is speaking about lies not only in opposing the images of a happy past and a gloomy present, but also in the ever-present in the texts lexical oppositions: Sonnenshein (sunshine) - Schatten (shadows), Jugend (youth) - Alter (old age), Morgens (mornings) - Abends (evenings), etc.

In a number of cases it is these oppositions that determine the timbre and texture of the choral score. In the third movement of the cycle, 'Abendphantasie' (Evening Reverie), the contrast between light and darkness ${ }^{4}$ in the second to last verse is reflected in a sharp change of register: male choir parts intoning in the one-line octave give place to an alto and bass ensemble singing in an extremely low tessitura. Syllabic uniformity in intoning the parts attracts attention, helping to clearly hear the opposition of the images in the text: 'Licht und Luft' ('light and air') and 'Dunkel' ('darkness'). For the record, a similar device

${ }^{3}$ It is remarkable, that by composer's own admission, at the time he was working on Phantasien he only knew about Holliger's experience of working with Hölderlin's texts, and he learned about Nono's compositions much later [3, p. 162]. As for Maderna's Hyperion, there is no doubt that Ligeti, who was close friends with Maderna, knew about the Italian composer's experience of working with Hölderlin's texts in the Hyperion versions, one of which (Hyperion II) was performed in Darmstadt in 1965.

${ }^{4}$ In licht und Luft zerrinern mir Lieb' und Laid'! -

Doch, wie verscheucht von thöriger Bitte, flieht

Der Zauberer; dunkel wirds und einsam

Unter dem Himmel, wie imme, bin ich [5]. 


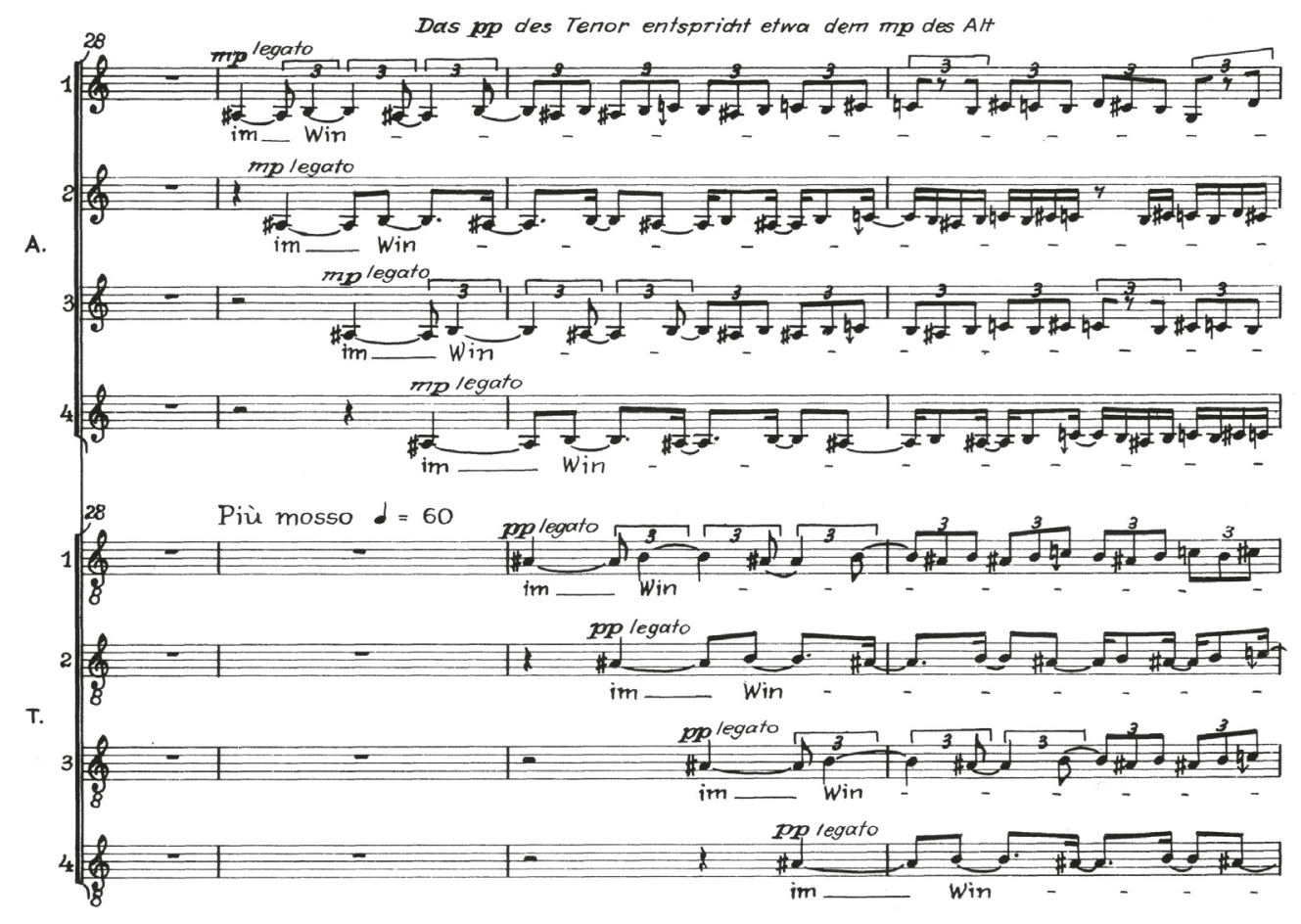

Example 1. G. Ligeti, Drei Phantasien nach Friedrich Hölderlin № 1 'Hälfte des Lebens'. Bars 28-31 (alto and tenor parts)

is used in all three movements of the cycle (see bars 20-22 in 'Hälfte des Lebens' / Halfway through Life/, bars 34-39 in 'Wenn aus Ferne' /If from a Distance/). Considering that this register contrast is typical for the Lux aeterna score (bars 94-109), one may say that the same style is manifested in the mentioned examples with the only difference that in cycle Drei Phantasien nach Friedrich Hölderlin the position of this device is determined by the content of Hölderlin's text.

One cannot but agree with the opinion of the researchers [3, p. 161-83; 4, p. 151-4] who insisted that the structure of a poetic text directly influences the architectonic of Ligeti's cycle ${ }^{5}$. However it is difficult to accept B. Englbrecht's idea that the main texture types have a specific semantic meaning: Ligeti uses this compositional and technical dichotomy - polyphonic canonical structures vs homogeneous and harmonic ones - as a reflection of the divide between the positive and the negative in Hölderlin's works [3, p. 169]. The researcher's conclusion is disproved by cases of reflecting both positive and negative images with various texture resources (e. g. in the first piece of the cycle, the negative image of a winter wind is realized through canonical texture, the same as the positive image of riping yellow pears; in 'Abendphantasie', both the positive night sky image and the negative loneliness image are attributed to homogeneous and harmonic composing). Rather, building on the composer's own words on the presence of madrigal stylistics ele-

${ }^{5}$ M. Searby writes the following about the cycle harmonic language: 'It also responds to the text in a much more direct and literal way than his earlier vocal works, which are more restricted by the micropolyphonic technique he was using at the time' [6, p. 127]. 


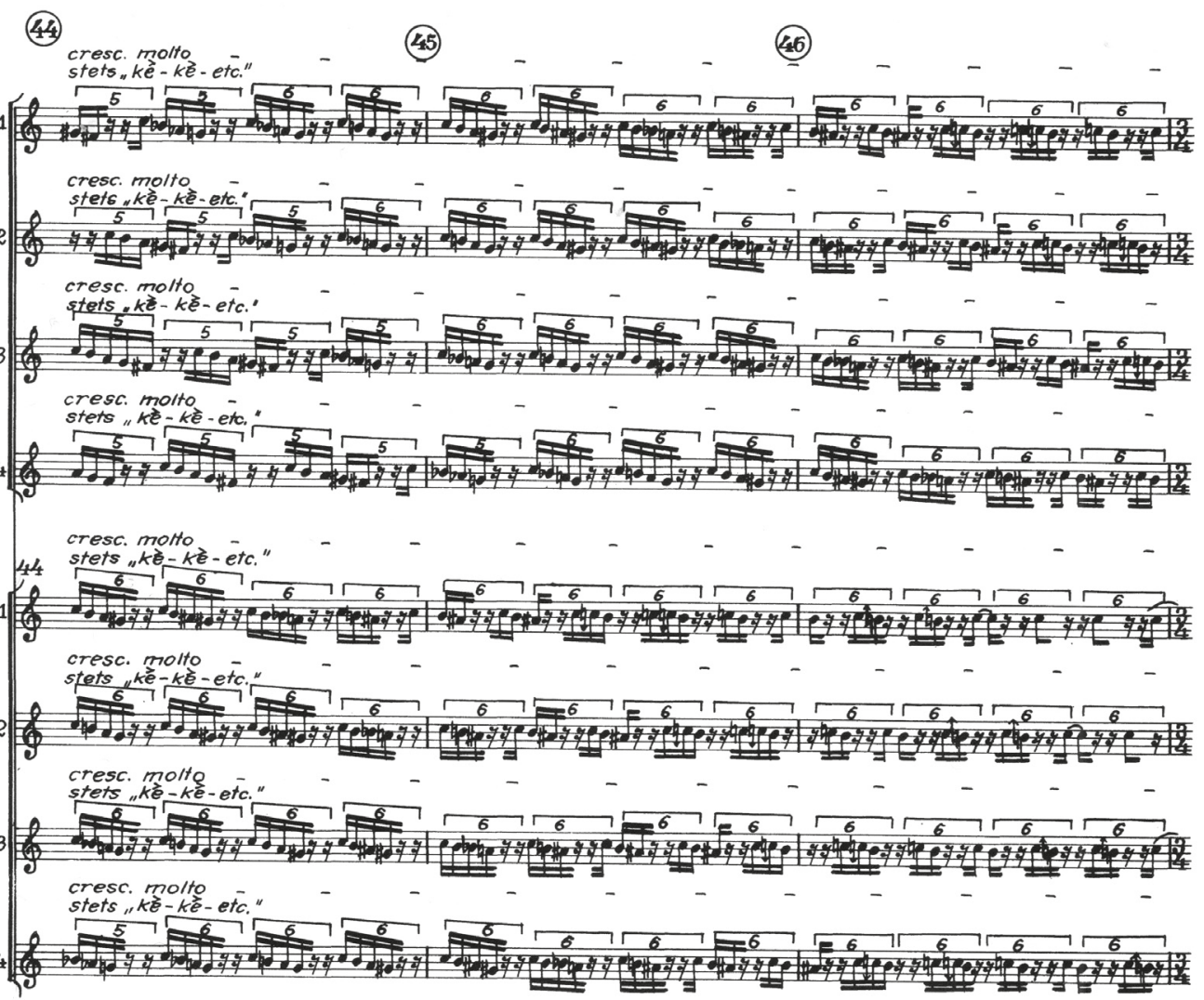

Example 2. G. Ligeti, Drei Phantasien nach Friedrich Hölderlin № 1 'Hälfte des Lebens'. Bars 44-46 (soprano and alto parts)

ments ${ }^{6}$ in the cycle, we can speak of equal employment of the two main texture types in the verse structure of the cycle pieces. Kin to madrigal masters of the $16^{\text {th }}$ century, Ligeti through alternation of different types of texture, tempo and quasi-tonal contrasts ${ }^{7}$ separates musical and poetical verses, while also paying attention to musical rhetoric devices, literally reflecting the content of separate words in the fabric of the music. So, in 'Hälfte des Lebens' the composer embodies the image of an increasing wind through sequential use of smaller and smaller rhythmical elements in polyrhythmical overlapping: interaction of duplets and triplets (Ex. 1) is substituted by simultaneous unfolding of triplets and quadruplets, in the climax giving way to the beat of quintuplets and sextuplets (Ex. 2). A similar dynamic picture also appears when embodying the image of flying in purple clouds ('Abendphantasie').

${ }^{6}$ Ligeti: 'Here [in Drei Phantasien nach Friedrich Hölderlin - A. R.] there are, I'd say, madrigal, musical and illustrative associations, but it is not putting a text on a melody in keeping with Schubert or Hugo Wolf $\langle\ldots\rangle$ I didn't want to simply compose music following the poem, such duplication could be in place in some literary opera, where composers slavishly obey the text creating music for it. I perceive this as a primitive, useless task' [7, p. 132].

${ }^{7}$ For example, one cannot but note the 'sharp' beginning of the second verse (bar 13) after the 'flat' first verse in 'Hälfte des Lebens'. 
Great importance in the cycle is also attributed to such typical madrigal exclamations of the hero ('Ach! Wehe mir' /'Oh! woe to me' - No. 2 'Wenn aus der Ferne'/, 'Dorthin nimmt mich, o!' /'Oh! get me out of there!' - No. 3 'Abendphantasie'/), clearly distinguished from the preceding musical content with chord verticals. Let us also add to these examples the already mentioned opposition of the images of light and darkness, initiating a climactic register contrast important to shaping all the cycle compositions. Numerous examples of such attentive reflection of Hölderlin's verses content in the choral score are related to a special composer's attitude, who explained his interest in the texts of the great German poet in the following way: 'What attracts me in Hölderlin is not so much the language level itself, as the level of illustrated associations' [8, p. 11].

In Drei Phantasien nach Friedrich Hölderlin Ligeti discovers new possibilities to work with the verbal series. Already in the first piece of the cycle, such typical for Nonsense Madrigals interest in simultaneous development of several verbal series announces itself. But while in his later piece the composer arranges the vocal texture by joining several various in origin verbal series, here he joins different parts of one verse played simultaneously. In the second movement of the cycle the composer chooses a similar method. Let us note that in both cases this experiment is carried out within the framework of a complex canonical texture preventing one from clearly hearing the underlying verbal text. While in instances when the important for the listener's perception words are emphasized through texture, polytextual representation is excluded.

Analogies in the compositional and dramaturgical approach of the pieces show not only the aforementioned piece climaxes, but their extreme divisions. Despite the lack of intonational indistinguishability, a feeling of recapitulation appears through using similar texture means. In the first piece, extreme divisions are united via similar texture pattern and the used rhythmic principle (combination of triplet and duplet motion). The final section of the second piece is a texture inversion of its first section: while in the beginning of the composition the canonical texture of female voices is unfolding against a stereomonody ${ }^{8}$ of male voices (tenor and a bit later bass), in the piece ending the canon is sung in lower voices against a stereomonody of female choir parts.

The texture arrangement of the third piece stands out, but here one can also observe a tendency towards textural repetition in the final verse of the composition. The beginning of 'Abendphantasie' hugely resembles Schoenberg's timbre and texture experiments in choral pieces: the inception of a dissonant chord from the all-choir unison literally repeats the start of choral piece Du sollst nicht, du mußt (op. 27 No. 2) with the only difference that Ligeti simultaneously builds a harmony vertical based on the melody tones, thus creating a fragment of a diagonal texture. In the last verse the composer uses the texture diagonal again, but in the form in which it was presented in Luigi Nono's 1950 s work $^{9}$ who also based his experiments on Schoenberg's experience.

Connection with the choral writing of the Head of the Second Viennese School can be also observed in the second piece of the cycle in which, as C. Floros states [4, p. 153-4],

${ }^{8}$ For the first time we applied the term stereomonody within the research of choral works of Italian avant-garde composers L. Nono and L. Berio: 'This unique composing style is a result of consistent turning of a one-voiced line, arranged with a certain timbre, into a monody of new kind that constitutes an entire texture layer with constantly changing timbre "content" [9, p.242].

9 In the opinion of R. Steinitz, typical for Ligeti's micropolyphony parallel use of length division into two, three, four, five parts is also evidence of Luigi Nono's influence, in particular of his cantata Il cnto sospeso [10, p. 151]. 
thematic invention of all canonical periods derives from the initial theme. The researcher sees in this free fraction of the variation form. However with as much grounds one may talk of an allusion to serial technique in Schoenberg's 1920s compositions, characteristic of which were both predominant use of canonical texture and reproduction of all intonational lines from a single source - the theme series.

Schoenberg's and partly Nono's experience became a natural component of Ligeti's own original writing, for whom, in contrast to all his colleagues and predecessors, the texture of musical compositions was just a means of achieving special sound effects, many of which (all-choir unison in the beginning of the piece, gradual escalation of sonority from the middle register simultaneously in two directions - up and down, creation of a dense sonorous field by means of canonical micropolyphony) had already been used in the 1960s-1970s works. In Drei Phantasien nach Friedrich Hölderlin, these devices are not only joined together, but they also develop. For example, in 'Abendphantasie' the composer actively uses juxtaposition of female (side note: normal singing) and male (side note: falsetto) voices verticals within one octave that for the first time was applied in the Lux aeterna score. This juxtaposition here does not so much create a spacial sound reflection effect, as embodies the opposition of the real and make-believe worlds in the consciousness of the main hero. Without resorting to the means of electronic music, Ligeti creates a new vocal sound by combining normal and falsetto ways of singing together with putting the voices in extreme tessitura conditions. It will just suffice to mention the effect produced by an ensemble of intersecting parts of alto 4 and falsetto bass 1 in bar 39 of the piece, the interval between the participants being a major seventh! A number of texture devices show putting a typical for Lux aeterna technique of 'timbre mimicry' in the conditions of working with a verbal series heard by the audience. In relation to this we should note an exceptionally difficult for a choir device when a harmony is inconspicuously transferred from the female to the male choir (falsetto) while the male choir intones new verbal material. Thus Ligeti disguises the timbre contrast between two verses, just like in Lux aeterna he was trying to abandon the clear perception of counted time within qualitative metrics.

One of timbre devices announcing themselves in the Clocks and Clouds (1973) score here is embodied for the first time using only vocal means. In the final section of 'Hälfte des Lebens' (text 'im Winde klirren die Fannen' /'a weather vane is squeaking in the wind'/), as part of micropolyphonic arrangement with gradual rhythmical acceleration, Ligeti dictates gradual transition from legato to non legato with simultaneous change of vocalisation (transition from vowel [e] to the neutral vowel). In bar 12 of the section the composer asks for crescendo with a distinctive transition to intoning the syllables 'he-he-he', which, obviously, is related to echoing the weather vane squeaks. This example is interesting in terms of the arising effect of the modulation of a 'cloud' (rhythmically amorphous sonority) into a distinctively metrised sound of 'clocks'10.

The reverse process of gradual 'dissipation' of metre or 'time banishment', as the composer defined it himself [12, p. 184], can be observed in the first piece of cycle Magyar

${ }^{10} \mathrm{~K}$. Beffa also paid attention to the mutually reversible modulations of such important for the texture arrangement compositions of late Ligeti metaphoric categories as 'cloud' and 'clocks' when speaking about the compositional intention of Clocks and Clouds: 'Do not let the name of the piece fool you: what interests Ligeti is not to present clouds and clocks as polar oppositions, but to research their possible modulations towards each other' [11, p.211]. 
Etüdök (1983) based on poems by Sándor Weöres ${ }^{11}$. Proceeding from the text, the composer paints a picture of spring dripping with consecutive inclusion of 12 choir parts reproducing imitative words of the Hungarian text, 'Csipp, csepp' (lit. 'drip-drop'). The last sound of the theme in each part is held for a lengthy period of time with gradual transition to intoning with one's mouth closed, as part of gradual sonority reduction. The arising effect of texture diminuendo parallel with appearance of a sonant, made of the final sounds of various theme transpositions, moves the piece from the level of 'clocks' to the level of 'clouds' with further disappearance of the latter (B. Englbrecht compared this process to evaporation of spring puddles [3, p. 123]).

It is remarkable, but for depicting such familiar and, it seems, very simple natural process the composer uses means of complex canonical technique presented in three varieties: canon in direct motion, proportional canon and canon in inversion. It is interesting that in the piece title he mentions only the name of the last technique - 'Spiegelkanon' ('Mirrored Canon'), apparently, ironically hinting both at spring puddle mirrors and the overall principle of the piece - reflecting a natural phenomenon in the vocal sound. The beginning of the score attracts with the proportional canon technique used by the composer, reviving in memory the famous Ligeti's composition for a 100 metronome, Poème symphonique: within one tempo and a single bar system, the duple metre of the second choir corresponds to the triple metre of the first choir. In such a way the composer achieves the effect of monotonous yet non-uniform 'dripping. Changes in the main theme rhythmic pattern in the parts (these mainly concern a decrease or an increase in the number of pauses within the theme) while keeping its pitch serve the same goal. We encounter the first use of the main theme mirroring almost in the middle of the piece, in bar 21, and after realization in a couple of tenor 1 parts of the first and second choirs the inversion maintains its leading position till the end of the piece. Thus, structurally the first piece is also divided into two sections, in the first of which only the direct motion canon is used together with the proportional canon technique, and in the second - the mirrored canon technique becomes the leading one while the first two are used as well (this feature also sends back to the piece title: the second part of the piece acts as a reflection of the first one).

In Ligeti's late work, Magyar Etüdök is the first vocal composition where the composer turns back not only to Sándor Weöres's poetry ${ }^{12}$, but to the sound of the Hungarian language itself. Probably, this return was inspired by the idea of an anniversary concert within which the composer summed up his work in a certain way. One can suppose that when creating this piece, mostly for the German audience, Ligeti understood the problem of perceiving the Hungarian language and intentionally chose poems from Weöres's collection that are marked with the use of onomatopoeia vocabulary, not requiring translation,

11 The history of creating cycle Magyar Etüdök is directly connected with Drei Phantasien nach Friedrich Hölderlin. As B. Englbrecht attests, in May 1963, at his anniversary concert, Ligeti was planning to present a German premiere of Drei Phantasien nach Friedrich Hölderlin performed by the Schola Cantorum Stuttgart choir conducted by Clytus Gottwald. But as the composer finished the score later than he had anticipated, Eric Ericson - the Swedish Radio Choir conductor who ordered the composition - postponed the premiere by half a year, so it could not be performed in Germany earlier by another choir. That is why the composer decided to substitute Drei Phantasien nach Friedrich Hölderlin at his anniversary concert with another composition, and he chose Magyar Etüdök. The first two parts of the new cycle were performed on May 18, 1963. The third part was performed on November 17 the same year [3, p. 115].

${ }_{12}$ Ligeti’s early choral pieces Magány (1946), Ejjzaka / Reggel (1955) are also composed to S. Weöres’s texts. 
recreating natural sounds. In this respect, the title of the cycle itself elicits not only musical associations (étude as a piece aimed at solving certain performance technical issues), but also refers you to the world of fine arts, where an étude is a sketch of the future piece, as a rule, painted from nature.

While the first piece recreates a scene of spring dripping, the second recreates a summer evening with insects' buzzing amalgamating with frogs' croaking and distant strokes of a church bell. In the piece title only the poem numbers are specified, taken from Weöres's collection (No. 49 and No. 40). This is the first case when Ligeti uses two texts in one choral composition. However, contrast to Nonsense Madrigals, here the composer does not resort to parallel development of independent verbal series, but rather integrates the second poem into the structure of the first one. Textual 'modulation' is ensured through the coincidence of the presented images: poem No. 49 contains a mention of 'frogs singing' to which echoing frogs' croaking corresponds in poem No. 40 . So, after the first verse of the first poem, the composer fully reproduces the second poem, and finishes the composition with the last verse of the first poem.

This textual three-part arrangement is matched also in the musical three-part structure, highlighted not only by common texture devices, but by recognizable intonational patterns of the main theme in the extreme sections of the form. The texture of these sections differs greatly from previous Ligeti's experience. The composer uses a double-choir arrangement where the second eight-voiced choir is meant to become an acoustic reflection of the first eight-voiced choir (the author's side note put above the second choir accolade says, 'echo'). The arising effect is very accurately described by L. Akopyan: '... in late Ligeti's works, unlike his early works, folklore and traditional elements are presented in a shifted perspective, through a haze of "clouds"' [13, p.303]. To a greater degree this shift of perspective is obvious in the recapitulation section where the composer builds a four-voiced female choir canon (the first choir), onto which its hardly audible 'copy' is laid (the second choir) shifted by an eighth in respect to the 'original'. Let us mention that such reverberatory effects of choral sonority also interested Luigi Nono in the 1980s. However to arrange an echo effect, Nono used Live electronics resources. Ligeti, who in the 1960s abandoned electronics, here also demonstrates his fidelity to the principle of looking for new sound solely through natural means. But saying that, the piece is characterised with typical for Ligeti's early work modal colouring. Starting from the first theme with clearly felt melodic tonics $a$ and $b$ and ending with the last chord consisting of pentatonic sounds dis-fis-gis-ais-cis, expanded with the his tone, the entire piece is perceived as a typical neomodal composition, in each section of which it is possible to distinguish melodic tonics. Even in the dynamic middle section based on echoing the frogs' croaking ('bre-ke-kex'), the church bell strikes ('Bam! Bim!'), the insects' buzzing (vocalisation of sonant [z]), one can still feel the reliance on certain tonal structures (most often on the pentatonic) in the choir parts horizontals.

The third piece of cycle Magyar Etüdök is somewhat isolated. It is the only one that has a title ('Fair') and detailed instructions for performers. Here the composer divides the choirs into five performing groups, four of which are separate choir parts of the first choir (with divisi in soprano and alto parts), and the fifth is a second (small) choir part that should include representatives of all parts. Each of the five groups, positioned at a certain distance from each other, has their own text (one of the five fragments of poem No. 90 from Weöres's collection), their own ostinato melodic (melodic and harmonic) 
part, and, most importantly, their own rhythm. What unites the parts of all performing groups is quadruple metre and the principle of constant dynamic development in different directions. The last instruction, making it possible to distinguish different groups of performers from the overall sound, is aimed at achieving spacial effects.

Overlapping of different rhythms also appears in Le Grand Macabre. However, in contrast to the more improvisational combination of several rhythms in the opera, here the composer demands the highest possible accuracy in reproducing different motion speeds ${ }^{13}$, which is also reflected in the musical notation. So, after each seven bars in the soprano group and after each eight bars in the alto group, the composer writes for them a common barline. The truth of this indication is supported by the following calculations: the duration of one counted beat of the soprano group with metronome set to quarter $=140$ is 0,4285714 second, while one counted beat of the alto group with metronome set to quarter $=160$ is 0,375 second. According to this, the duration of eight bars of the alto group is 12 seconds $(8 \times(0,375 \times 4)=12)$, the same as the duration of seven bars of the soprano group $(7 \times(0,4285714 \times 4) \approx 12)$. To ensure adherence to the indicated rhythms, Ligeti suggests not only employing assistant conductors, but also providing them with special headphones tuned in to a metronome signal. It is also possible to use a light indicator of the metronome beat. However when recording this unique polyrhythm canon in a studio, Ligeti recommends to mechanically coordinate the recordings of all five groups.

Seeing polyphony as the key principle behind a choral piece both on the texture and the content level (contrapuntal combination of various texts and, in a broader sense, multilayered meaning) logically leads Ligeti to writing a climatic vocal ensemble opus, cycle Nonsense Madrigals (1988-1993). Six years before he started working on this composition, in Drei Phantasien nach Friedrich Hölderlin, Ligeti clearly touches upon neomadrigal style in the compositional and technical arrangement of his choral pieces, with the following result:

a) a motet and verse arrangement of the form, within which the logic behind musical formation is subordinate to the poetic text structure;

b) texture based on interconnection of the two main for the madrigal setting types: harmonic, and imitation and polyphonic (canonlike) ones;

c) the phenomenon of interconnection of a verbal text content and musical series intonational setting, which drives resorting to musical and rhetorical figures (the so-called 'madrigalisms').

In this respect, Nonsense Madrigals is not just a sort of a postmodernist fancy aimed at playing with poetics of an ancient genre, but a piece logically concluding the development of Ligeti's vocal ensemble work. Working on a composition intended for the famous ensemble The King's Singers, Ligeti reflected varied stylistic allusions in the score greatly corresponding to the ensemble's huge performance range ${ }^{14}$ and his own wide musical interests. Alongside a polytext motet (No. 1), a passacaglia (No. 4), a quadrille (No. 5), a jazz

13 The score preface states: 'Insignificant deviations from synchronous performance are allowed $<\ldots>$ However, too great an inaccuracy in synchronous performance can destroy the harmonious structure' [14, p.28].

14 The King's Singers' repertoire contains both Ars Nova and Renaissance vocal masterpieces and $20^{\text {th }}$ century academic and popular music. 
piece (No. 6) the cycle also includes Ligeti's self-parody on his own 1960s choral writing (No. 3), that becomes a constituent part of this stylistic 'kaleidoscope' ${ }^{15}$.

The choice of texts for Ligeti's madrigals, surprising at first sight (children's poems as a verbal foundation for an ancient vocal genre), - is quite logical. The composer's love for Lewis Carroll's works is well-known, and his desire to compose an opera based on $\mathrm{Al}$ ice's Adventures in Wonderland (Ligeti was planning to start it after finishing vocal pieces Aventures and Nouvelles Aventures) eventually was partly realized in cycle Nonsense Madrigals, most compositions of which are linked not only with Carroll's texts but also with the atmosphere of absurd, nonsense so typical for the British children's literature of the Victorian era. The latter also dictates using texts of another two poets besides Carroll William Rands and Heinrich Hoffmann. Written independently and almost at the same time, these texts initiate various links on the content level that unite the entire cycle. This concerns not only the general atmosphere of nonsense, but also the hints at the presence in this composition of the two most important themes for a $16^{\text {th }}$ century madrigal, i.e. love and death. Both themes appear in the composition disguised - through comparison of poetical texts or through verbal and musical allusions. So, in the polytext texture of the first madrigal, images of a boy and a girl appear through simultaneous presentation of two Rands's poems: the link between these images is highlighted not only by a common content, but by unified syntax constructions in the poetical texts. And the idea of interdependence of these images is emphasized with the help of texture devices: melodic and harmonic material in the higher voices (alto parts) presenting the girl's image (poem: 'The Dream of a Girl who Lived at Seven-Oaks') is intonationally reflected in the lower voices material (baritone parts) presenting the boy's image (poem: 'The Dream of a Boy who Lived at Nine-Elms') (Ex. 3).

The theme of love asserts itself more distinctly in the second madrigal, despite no clear hints at its presence in the Rands's poetic text. In B. Englbrecht's opinion, who pointed out intonational similarity of the starting madrigal phrase with the melody of popular song Grüß Gott, du schöner Maien (Exs. 4a, 4b), such musical parallel makes it possible to present a children's poem not as a dialog of a cuckoo and an abstract author, but rather as a conversation of two lovers: '....in this way Ligeti fixes the meeting of the cuckoo with her beloved one in time [spring. - A.R.] and distinctively hints at all erotic connotations linked with this season that are especially felt in such peculiar poem context' [3, p.57].

The theme of death for the first time clearly appears in the fourth madrigal telling of a disobedient boy Robert whom the wind carried high up into the sky in foul weather. Hoffmann's poem finishes with a frightening uncertainty of the last verse:

'No one ever yet could tell,

Where they stopp'd, or where they fell;

Only this one thing is plain,

Bob was never seen again!' [15, p. 26].

${ }^{15}$ It is possible, that 'The Alphabet' sonant piece was included into Nonsense Madrigals out of the composer's wish to create such typical for his choral writing timbre modulations by means of a relatively small number of voices. Of no small importance is the unique vocal lineup of The King's Singers, a male ensemble that nevertheless has a range comparable to that of a mixed choir: Ligeti's piece is written for a bass, three baritones, a tenor and two countertenors (male altos). 


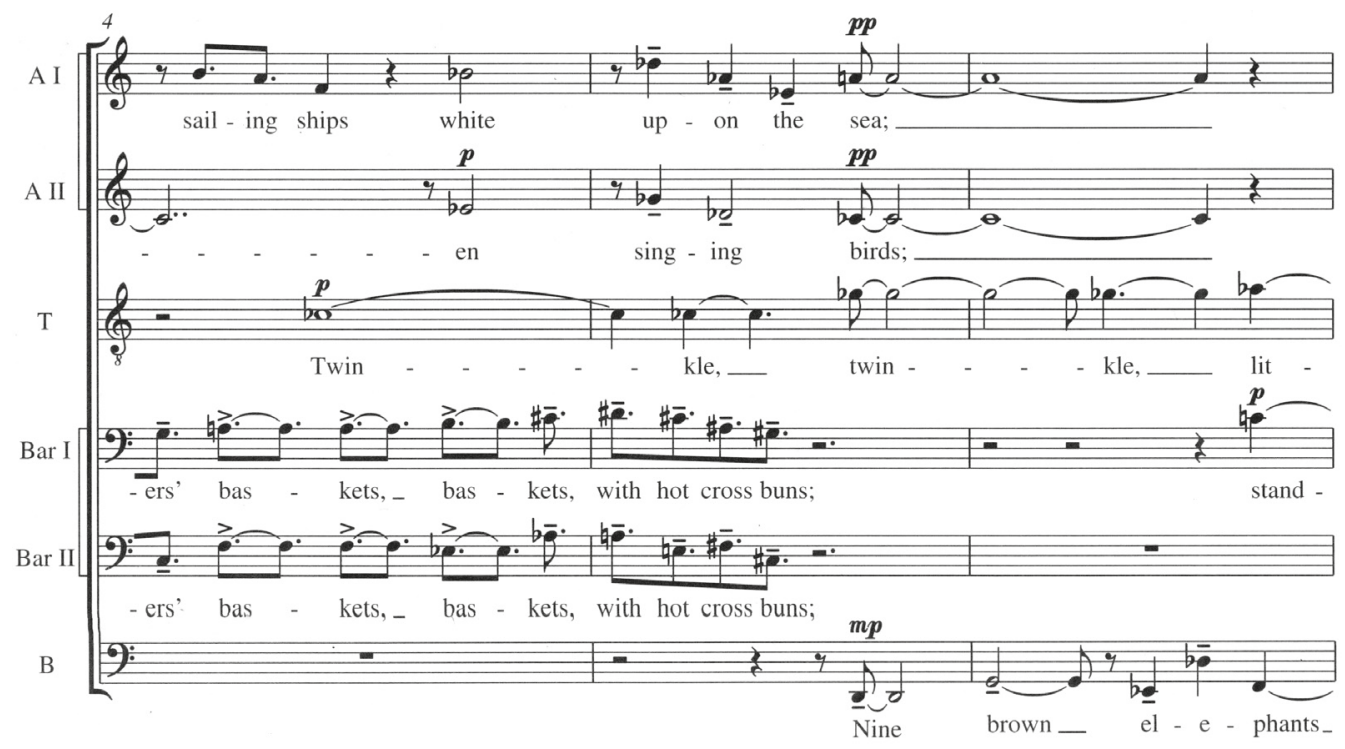

Example 3. G. Ligeti, Nonsense Madrigals No. 1 'Two Dreams and Little Bat'. Bars 4-6

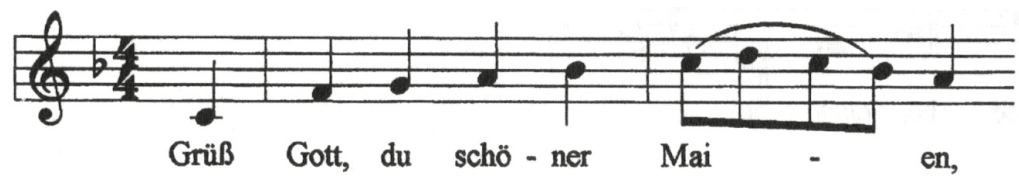

Example 4a. Song Grüß Gott, du schooner Maien, fragment

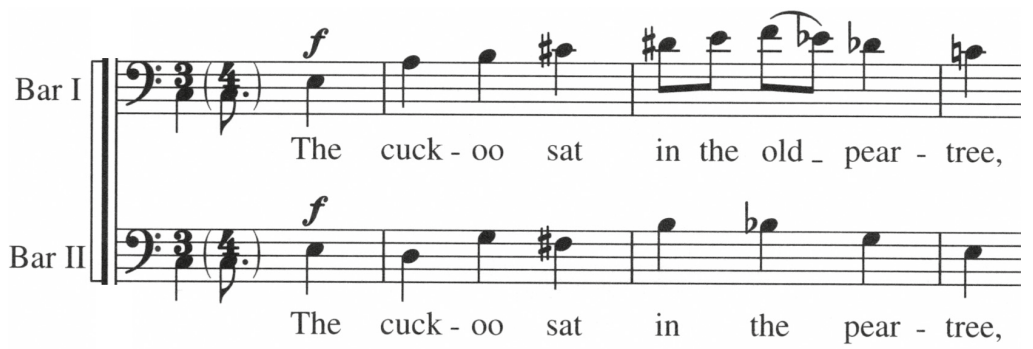

Example 4b. G. Ligeti, Nonsense Madrigals, No. 2 'Cuckoo in the Pear-Tree'. Bars 1-3

The composer additionally amplifies the obvious hint at the fatal outcome by choosing the passacaglia genre that in the Baroque Era serves as one of the means to depict tragic images. The connection with a passacaglia is highlighted by the presence in the texture of a repeated ostinato intonational figure ('Comes down, rain comes down').

In the fifth madrigal, a playful dialog of two characters - a hake and a snail - includes mentions of England's and France's shores ${ }^{16}$ backed up by allusions on national

16 "'What matters it how far we go?" his scaly friend replied.

'There is another shore, you know, upon the other side.

The further off from England the nearer is to France...' (L. Carroll, Alice's Adventures in Wonderland. Chapter 10: The Lobster Quadrille [16, p. 94]). 
anthems of these countries. Text 'The further off from England the nearer is to France' is perceived by the snail as a mortal danger, emphasized in the transformation of the British national anthem into an ominous (for the snail ${ }^{17}$ ) image of La Marseillaise. This combination of the tragic and the comical in the sound of the fifth madrigal is highly typical for the composer who once said: 'buffa and seria, comedy and fear, are not simply mixed, but are rather two sides of ... the same coin: the serious is always comic, and the comic frightening' [17, p. 222].

The sixth madrigal is based on 'A Long, Sad Tale' of the Mouse (Alice's Adventures in Wonderland. Chapter 3: A Caucus-Race and a Long Tale) about the cat's suggestion to bring the Mouse to trial and condemn it to death. The piece starts with the Queens phrase addressed to Alice: 'Off with her head', and its end with the first in the whole cycle pronounced word 'death' additionally draws the listeners' attention to this important for a madrigal theme. Ye. Traynina underlines the consistency of such a cycle finale: 'The most hidden, deep paradox of a nonsense is inherent to it subtext of the destruction of all creation, despite its external joyfulness and carelessness $\langle\ldots\rangle$ In Ligeti's works this idea shows in the "sad" mood prevailing in the selected texts and a respective attitude of the Carroll's fairytale characters to the stories they tell. This is especially highlighted in the ending of the last madrigal, with the word "death" [18, p.411].

The end of the last madrigal with the word 'death' also creates a link with the title of the first madrigal - 'dream', that in this context is perceived not only as a 'girl's dream' or a 'boy's dream', but also as a metaphor of death. In creating parallels between the first and the last madrigals, their common polytext arrangement plays an important role. While the verbal arrangement of the first madrigal is related to parallel polyphonic development of Rands's and Carroll's texts, the verbal foundation of the sixth madrigal is like a homogeneous and harmonic structure: the relief of a melodic and harmonic complex presenting the Mouse's sad tale is set against a background of Carroll's doublets ${ }^{18}$, borrowed from his brochure 'Doublets, a word puzzle' [19].

The central - the third madrigal 'The Alphabet' - despite having no generally accepted text, is connected not only with the general idea of the cycle through accurate following of the idea announced in the title (Nonsense Madrigals), but also with the meaning of the first madrigal where the role of the cantus firmus is attributed to the famous children's song ${ }^{19}$, presented by Carroll with another - absurd - text (Alice's Adventures in Wonderland. Chapter 7: A Mad Tea-Party). As Ye. Traynina says, 'possibly, it is this children's song used as cantus firmus that conditioned the third part of the analyzed opus, "The Alphabet", because its melody is used to teach fast memorising of the English alphabet' [18, p. 413]. B. Englbrecht proves the logic behind the third madrigal in the cycle through its link to the world of childhood: 'the alphabet is a part of a child's life' [3, p. 63]. Agreeing with these statements, we will also point out the important dramaturgical function of the third madrigal that via its 'zero' semantic level divides the two mentioned mad-

17 Snail is the main component of a popular in France delicacy Escargots de Bourgogne.

18 Doublets is one of Carroll's favourite games. Its point is in creating word chains consisting of the same number of letters, inside which source words are transformed into new ones. The most interesting is a transformation of a word into its opposite one (in terms of meaning). One of perfect examples used in Ligeti's madrigal is the transformation of a head into a tail: head - heal - teal - tell - tall - tail.

19 French song Ah! vous dirai-je, maman, first published in 1761, is known in the UK as lullaby Twinkle, Twinkle, Little Star put on the text of Ann and Jane Taylor from their collection Rhymes for the Nursery (1806). 
rigal themes - love and death. Saying all this, 'The Alphabet' does not boil down solely to Ligeti's self-parody like Lux aeterna, but becomes a composition close in its idea to the famous Aventures: despite lack of verbal content, one can feel existential problematics in the spirit of Aventures. This is especially obvious in the ending of the piece, when in intoning ' $y$ ' [wai] - a homophone of the famous philosophical question 'why?' - Ligeti, by putting a question mark, insists on a certain sense: this could be both a question of hope (rising intonation) and a sorrowful sigh of disappointment (descending intonation).

Musical allusions on the madrigal genre in Nonsense Madrigals also include both the madrigalism ${ }^{20}$ device that is used in Drei Phantasien nach Friedrich Hölderlin and texture features - priority of the canonical and harmonic types of setting, as well as a complex temporal arrangement of the pieces based on combination of binary and ternary arrangement. The latter can be considered both as a hint at co-existence of tempus perfectum and tempus imperfectum of the Middle Ages and the Renaissance, and as a reflection of the time management principles in late avant-garde compositions (using a small length as a single temporal measure, in relation to which simultaneous binary and ternary motions develop). The use of cantus firmus in the first madrigal reflects a connection with a device appearing in some Marenzio's madrigals (e.g. madrigal Occhi lucenti e belli), when one of the voices, presented only in large lengths, creates a hint at a typical texture of an ancient mass. And even children's poems as the textual foundation of the cycle can be viewed as an ironic hint at the genre name: madrigal as a song in one's mother's language, i. e. the language that is used from childhood to sing and tell children's songs, poems and fairy tales.

Nonsense Madrigals is the climax in Ligeti's vocal ensemble and choral writing. All the lines, connecting the 1960s vocal music and the 1980s compositions joined together in this cycle: we can observe micropolyphonic arrangement from Requiem, detailed vocal articulation of Aventures and neomadrigal tendencies of Drei Phantasien nach Friedrich Hölderlin and Magyar Etüdök in parallel. This organic combination of the key elements of Ligeti's vocal style in his last vocal ensemble composition enables us to talk of the composer's choral writing as of a uniquely integral phenomenon, different stages in the evolution of which are characterised with keeping two quintessential musical and technical principles - micropolyphony and 'calm expressionism' ${ }^{21}$, that vividly distinguish Ligeti in the choral art of the second half of the $20^{\text {th }}$ century.

\footnotetext{
${ }^{20}$ Among those, the used madrigalisms are:

'running' - use of scale-wise motion framed with fine rhythm;

'sad' - inclusion of a descending second intonation;

'death' - quiet d-moll in a low register;

'nine little drummer-boys' - use of a characteristic 'drum rhythm': an eighth and two sixteenth;

'The cuckoo flew over a housetop high' - use of an ascending melodic line in the twelfth range;

'It whistles through the trees' - inclusion of a fast scale-wise motion up and down, use of whistling.

${ }^{21}$ In an interview to P. Varnai, speaking of stylistic elements of the Second Quartet, Ligeti concisely determined the main technical principles of his works: 'Consequently, I could say that the Second Quartet is a synthesis, if only I did not dislike the word. There is everything in it: Bartók's initial influence, a tone of voice recalling Stravinsky and Alban Berg and all the characteristic features of my own music, the micropolyphony of Atmosphères and the cooled expressionism of Aventures' [1, p. 16].
} 


\section{References}

1. Ligeti, G., P. Várnai, J.Häusler, and C. Samuel. György Ligeti in Conversation with Péter Várnai, Josef Hääusler, Claude Samuel, and Himself. London: Eulenburg, 1983.

2. Trainina, Elena. "Pozdnii 'Ligeti-stil" (proizvedeniia 1990-kh - 2000-kh godov)". PhD diss. Rossiiskaia akademiia muzyki imeni Gnesinykh, 2013. (In Russian)

3. Engbrecht, Berndt. Die spate Chormusik von György Ligeti. Frankfurt am Main: Peter Lang GmbH, 2001.

4. Floros, Konstantin. György Ligeti: Beyond Avant-garde and Postmodernism. Translated by Ernest Bernhardt-Kabisch. Frankfurt am Main: Peter Lang GmbH, 2014.

5. Hölderlin, Friedrich. Gedichte. Stuttgart u. a., 1826. Accessed July 01, 2018. http://www.deutschestextarchiv.de/book/view/hoelderlin_gedichte_1826/?hl=Abendphanta \%C5\%BFie;p=55.

6. Searby, Michael. D. Ligeti's Stylistic Crisis. Transformation in His Musical Style. 1974-1985. Lanham; Maryland: The Scarecrow Press, Inc., 2010.

7. Lichtenfeld, Monika. “...und alles Schöne hatt’ er behalten”. Fragmente zu Ligetis Ästhetik”. In György Ligeti: Personalstil - Avantgardismus - Popularität, Hrsg. Otto Kolleritsch, 122-33. Wien: Universal Edition, 1987.

8. Lichtenfeld, Monika. “Gespräch mit György Ligeti“. Neue Zeitschrift für Musik, no. 145/1 (1984): 8-11, Heft 1 .

9. Ryzhinskii, Aleksandr. "L. Nono, B. Maderna, L. Berio: puti razvitiia ital'ianskoi khorovoi muzyki vo vtoroi polovine XX veka". DA diss. Rossiiskaia akademiia muzyki imeni Gnesinykh, 2016. (In Russian)

10. Steinitz, Richard. György Ligeti. Music of the Imagination. Boston: Notheastern University Press, 2003.

11. Beffa, Karol. György Ligeti. Paris: Fayard, 2016.

12. Burde, Wolfgang. György Ligeti. Zürich: Atlantis Musilbuch, 1993.

13. Akopian, Levon. Muzyka XX veka. Entsiklopedicheskii slovar'. Moscow: Praktika, 2010. (In Russian)

14. Ligeti, György. Magyar Etüdök. Partitur. Mainz: Schott, 1983.

15. Hoffman, Heinrich. Struwwelpeter. New York: Dover Publications, 1995.

16. Carroll, Lewis. Stories, Verses, Puzzles, Acrostics, "Phantasmagoria" and Other Comic Writings - Illustrated by John Tenniel. London: Wordsworth Editions Limited, 2006.

17. Lobanova, Marina. György Ligeti. Style. Ideas. Poetics. Translated by Marc Shuttlewort. Berlin: Verlag Ernst Kuhn, 2002.

18. Trainina, Elena. "Nonsense madrigals Ligeti ili kategoriia 'absurda' (v dukhe postmodernizma)". In Federal'noe agentstvo po kul'ture i kinematografii, Rossiiskaia akademiia muzyki imeni Gnesinykh. Muzykovedenie $k$ nachalu veka: proshloe i nastoiashchee. Mezhdunarodnaia nauchnaia konferentsiia, 30 oktiabria - 1 noiabria 2007, edited by Tat'iana Naumenko, 408-16. Moscow: RAM im. Gnesinykh, 2007. (In Russian)

19. Carroll, Lewis. Doublets, a word puzzle. London: Macmillan, 1879.

20. Okuneva, Ekaterina. "O smyslovom prostranstve Nonsense madrigals D’erdia Ligeti". In Mūzikas zinātne šodien: pastāvīgais un main̄̄gais. Zinātnisko rakstu krājums, red. Ilma Grauzdina, 253-6. Daugavpils: Daugavpils Universitāte, 2015, produkcija VII. (In Russian)

Received: June 23, 2018

Accepted: August 30, 2018

Author's information:

Aleksandr S. Ryzhinskii - Dr. Habil.; loring@list.ru

\section{Особенности хорового письма в поздних сочинениях Д. Лигети}

\section{А. С. Рыжинский}

Российская академия музыки имени Гнесиных, Российская Федерация, 121069, Москва, ул. Поварская, 30-36

Для цитирования: Ryzhinskii, Aleksandr. “Characteristics of Choral Writing in György Ligeti's Late Works”. Вестник Санкт-Петербургского университета. Искусствоведение 8, no. 4 (2018): 57892. https://doi.org/10.21638/spbu15.2018.403 
Статья посвящена последним вокальным сочинениям a cappella, созданным Дьёрдем Лигети в 1980-1990-х годах: циклам «Три фантазии на тексты Фридриха Гёльдерлина», «Венгерские этюды» и «Бессмысленные мадригалы». Автор прослеживает связи с ранее созданными хоровыми опусами мастера, а также с хоровым творчеством предшественников и современников композитора, выявляя особенности развития хорового письма Лигети в его поздних сочинениях на уровнях взаимодействия слова и музыки, фактурной и тембровой организации. Особое внимание автор уделяет изучению неомадригальных тенденций в рассматриваемых произведениях. Устанавливается, что связь со старинным жанром прослеживается не только в устройстве музыкальной ткани, тесно связанной со строением словесного текста, или в чутком следовании интонационно-фактурного решения за литературным содержанием, но также и на уровне общего решения сочинений. В этом отношении кульминационным в наследии Лигети становится его цикл «Nonsense madrigals», в котором оппозиция любви и смерти - извечных категорий человеческого бытия - определяет композиционное и драматургическое строение цикла, а типичная для вокального творчества Лигети «полифония смыслов» проявляется в постоянной жанрово-стилевой игре с реципиентом. Сочинение, предназначенное для ансамбля «The King's singers» воплощает многообразные стилевые аллюзии, во многом соответствующие широкому исполнительскому диапазону ансамбля и собственным музыкальным интересам композитора. В этом последнем вокально-ансамблевом произведении Лигети отразилась и его любовь к литературному миру Льюиса Кэрролла с типичной для него атмосферой абсурда, нонсенса, столь созвучной музыкальному миру автора «Le Grand Macabre».

Ключевые слова: Дьёрдь Лигети, Арнольд Шёнберг, Луиджи Ноно, Льюис Кэрролл, Фридрих Гёльерлин, хоровая музыка, хоровая фактура, вокальная тембрика, неомадригализм.

Контактная информация :

Рыжинский Александр Сергеевич - д-р искусствоведения; loring@list.ru 